\title{
気泡噴流法による溶融 $\mathrm{Al}-\mathrm{Cu}$ 合金中の $\mathrm{Al}$ および $\mathrm{Cu}$ 活量の测定*
}

三谷裕 康 ${ }^{* *}$ 永并宏***

Hiroyasu Mitani and Hiroshi Nagai : Determination of the Activities of Aluminum and Cupper in Liquid Al-Cu Binary Alloys by the Bubbling Method. On utilizing the subhalide reaction to the aluminum refining process, it is very important to know the reactivity between crude aluminum alloys and aluminum trichloride. However, very little work has been reported concerning the influence of the alloying elements in crude aluminum alloys on this reaction.

In a previous work, the reactivity of $\mathrm{AlCl}_{3}$ with liquid $\mathrm{Al}-\mathrm{Si}$ and $\mathrm{Al}-\mathrm{Fe}$ binary alloys was investigated by the bubbling method, and at the same time the activities of Al in these alloys were determined.

In this report, the reactivity between $\mathrm{AlCl}_{3}$ and liquid $\mathrm{Al}-\mathrm{Cu}$ binary alloys in the composition range $0<N_{\mathrm{Cu}}<0.574$ was investigated by the same method. Combining the equilibrium constant determined in the previous work with the experimental data on these alloys, the activities of $\mathrm{Al}$ and $\mathrm{Cu}$ were determined at $1200^{\circ}$ and $1100^{\circ} \mathrm{C}$. The activities of $\mathrm{Al}$ show a large negative deviation from Raoult's law below 70 at $\%$ Al. The activity curve was found to be similar in shape to that obtained by Wilder, who determined the values by e, m. f. measurements using a molten chloride electlyte at $1100^{\circ} \mathrm{C}$.

Moreover, from the reaction ratio and the flow rate of $\mathrm{AlCl}_{3}$ obtained in the present experiment, the relations among the transporting velocity of $\mathrm{Al}$, the flow rate of $\mathrm{AlCl}_{3}$ and the composition of $\mathrm{Cu}$ were discussed.

(Received July 22, 1968)

\section{I. 粕}

アルミニウムと三塩化アルミニウムとの不均化反応を利

** 大阪大学工学部冾金学教室 (Department of Metallurgy, Faculty of Engineering, Osaka University, Osaka)

*** 大阪大学大学院 (Graduate Student, Osaka University, Osaka)

* アルミニウムの乾式製鍊に関する研究 (第 3 報)
用したサブハライド・アルミニウム製鍊の原料となるつ ルミニウム合金の製造方法として，ボーキサイトを直接睘 元して Al-Si-Fe 合金を得る力法 ${ }^{(1)}$ およびアルミナを直接 還元した場合に起こるアルミニウムの炭化物形成を抑制す るためにっアルミナと銅との混合物を直接還元して Al-Cu

(1) M.M.Striplin and W.M.Kelley: Chem. Eng.Progr, $43(1947), 569$. 


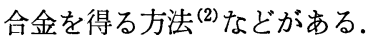

著者らは前報 ${ }^{(3)}(4)$ に扔いて，溶融了ルミニウム試料中に 三塩化アルミニウムガスを気泡噴流させることにより反応 を平衡に到達せしめ, 本反応の平衡恒数を測定した。ささら に上記の $\mathrm{Al}-\mathrm{Si}-\mathrm{Fe}$ 合金を原料とする場合の基碟的な研究 として, 溶融 Al-Si 2 元合金 ${ }^{(3)}$ 抢よび溶融 Al-Fe 2 元合 金 ${ }^{(4)}$ と三塩化アルミニウムとの反応性を追究し，同時にこ れら溶融アルミニウム合金中のアルミニウムの活量を測定 した.

本報では前報と同様の気泡噴流法により，上記の $\mathrm{Al}-\mathrm{Cu}$ 合金を原料とした場合を対象として溶融 A1-Cu 2 元合金と 三塩化アルミニウムとの反応性を追究し，その結果からさ きに求めた平衡恒数を活用して, 溶融 $\mathrm{Al}-\mathrm{Cu} 2$ 元合金中の $\mathrm{Al}$ 㧊よび $\mathrm{Cu}$ の活量を $1200^{\circ}$ 打よび $1100^{\circ} \mathrm{C}$ で求めた.

一方測定した三塩化アルミニウムの反応率技よび供給速 度から，反応によつて輸送されるアルミニウムの輸送速度 を計算し，アルミニウムの輸送速度に拉よぼす銅含有量招 よび反応温度の影響を検討した。

\section{II、試 料および実験方法}

\section{1. 試料}

実験に供した A1-Cu 2 元合金試料は Table 1 と示した

Table 1 Chemical composition of test alloys

\begin{tabular}{l|c|l}
\hline & $\mathrm{Cu}($ wt \%) & $N_{\mathrm{Cu}}$ \\
\hline 1 & 18.5 & 0.088 \\
2 & 32.3 & 0.169 \\
3 & 49.2 & 0.292 \\
4 & 60.7 & 0.396 \\
5 & 69.2 & 0.488 \\
6 & 76.0 & 0.574 \\
\hline
\end{tabular}

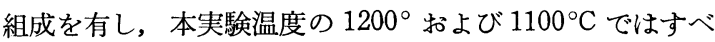
て均一な融体である。試料の作成にあたつては，99.99\% の高純度 $\mathrm{Al}$ と電解銅を配合し，黒鉛ルッボで溶解した。 これを金型に鋳込み，切断して溶解試料に供した。

\section{2. 実験方法}

実験に用いた装置および実験方法は前報 ${ }^{(3)}$ (4) とほとんど 同様である. 反応管内を真空加熱 $\left(200^{\circ} \mathrm{C}, 6\right.$ 時間 $)$ により十 分に清浄にした後，精製アルゴンガスで置換した．密閉管 内に拈ける所定の場所に Al-Cu合金試料を高純度アルミナ 製ルツボに入れて挿入し，精製アルゴンガス気流中で所定 の反応温度に昇温した。しかる後昇華精製した $\mathrm{AlCl}_{3}$ を $180^{\circ} \mathrm{C}$ 以下の一定温度に保つて㫒華発生させ，精製アルゴ ンを搬送ガスとして溶融 $\mathrm{Al}-\mathrm{Cu}$ 合金中に気泡噴流せしめ, $\mathrm{AlCl}_{3}$ ガスと溶融 $\mathrm{Al}-\mathrm{Cu}$ 合金とを不均化反応させた.

(2) P.Weiss : Z.Erzbergbau.Metallhuttenw., 7 (1954), 189.

(3) 三谷, 永井 : 本誌, 31 (1967), 1296.

(4) 三谷, 永井 : 本誌, 32 (1968), 752 .
実験条件は前報の $\mathrm{Al}-\mathrm{Si}$ 合金 ${ }^{(3)}$ 抽よび $\mathrm{Al}-\mathrm{Fe}$ 合金 ${ }^{(4)}$ の場 合とほとんぞ同様である. 気泡噴流管の孔径 $2 \mathrm{~mm} \phi$, 噴 流管の浸入深さを $15 \mathrm{~mm}$ とした。 また反応温度を $1200^{\circ}$ および $1100^{\circ} \mathrm{C}$ とし，反応時間は $\mathrm{Al}$ 反応量がほぼ $1 \mathrm{~g}$ とな るように反応温度拉よび $\mathrm{A} 1-\mathrm{Cu}$ 合金試料の組成に応じて 60〜180 min とした．ただし搬送ガス（アルゴン）と $\mathrm{AlCl}_{3}$ との混合モル比は, $\mathrm{AlCl}_{3}$ ガス発生容器内外 2 ケ所の温度 調節によつて約 2 とした.

\section{III. 実 験 結 果}

本実験に淤ける溶融 $\mathrm{Al}-\mathrm{Cu}$ 合金と $\mathrm{AlCl}_{3}$ との不均化反応 は次式で表わされる。

$$
2 \mathrm{Al} \text { (l) (Al-Cu Alloys) }+\mathrm{AlCl}_{3}(\mathrm{~g})=3 \mathrm{AlCl}(\mathrm{g})
$$

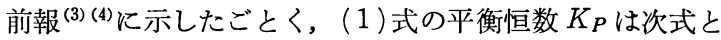
なる。

$$
K_{P}=27 \alpha^{3} /(1-\alpha)(1+2 \alpha+b / a)^{2} \cdot a_{\mathrm{Al}}^{2}
$$

ここで $\alpha$ は $\mathrm{AlCl}_{3}$ の反応率, $b / a$ はアルゴンガスと $\mathrm{AlCl}_{3}$ ガ スとの混合モル比， $a_{\mathrm{Al}}$ は溶融 $\mathrm{Al}-\mathrm{Cu}$ 合金中の $\mathrm{Al}$ 活量を 示している.ただし $\mathrm{AlCl}_{3}$ の反応率 $\alpha$ とは送つた $\mathrm{AlCl}_{3}$ ガ ス中の反応関与した $\mathrm{AlCl}_{3}$ の割合を意味し，次式から求 まる。

$\alpha=\{$ 合金試料の減量 $(\mathrm{g}) /$ 送つた $\mathrm{AlCl}_{3}$ 量 $\left.(\mathrm{g})\right\} \times 133.35 / 53.96$

(3)式に打ける合金試料の減量には， $\mathrm{Al}$ 扐よび $\mathrm{Cu}$ の蒸発 による減量も含まれるすのと考只られる。しかるに，純 A 护よび純 $\mathrm{Cu}$ を試料とした場合について，下記の蒸気圧 ${ }^{(5)}$ から $1200^{\circ} \mathrm{C}$ に打ける蒸発による減量を計算すると，純 $\mathrm{A} 1$ の場合 $7.1 \times 10^{-2} \mathrm{mg}$, 純 $\mathrm{Cu}$ の場合 $5.7 \times 10^{-2} \mathrm{mg}$ となり, 全減量約 $1 \mathrm{~g}$ に対してきわめて小さく，Al および $\mathrm{Cu}$ の蒸 発による減量の影響を無視することができる.

$$
\left\{\begin{array}{l}
\log p_{\mathrm{Al}}(\mathrm{mm} \mathrm{Hg})=-16450 / T-1.023 \log T+12.36 \\
\log p_{\mathrm{Cu}}(\mathrm{mm} \mathrm{Hg})=-17520 / T-1.21 \log T+13.21
\end{array}\right.
$$

ただし，搬送ガスは流速に影響なく $\mathrm{Al}$ および $\mathrm{Cu}$ の蒸気 を飽和して輸送するものとし，本実験で搬送ガスを最も多 量に使用した条件について計算した。

一方, 平衡恒数 $K_{P}$ は定温で一定であるから, $\mathrm{Al}-\mathrm{Cu}$ 合 金試料と $\mathrm{AlCl}_{3}$ とを反応せしめると, 各試料の $\mathrm{Al}$ 活量 $a_{\mathrm{Al}}$ に対応して(2)式に括ける $\left\{27 \alpha^{3} /(1-\alpha)(1+2 \alpha+b / a)^{2}\right\}$ の 值が変化する.

$$
K_{P_{\mathrm{Cu}}}=\left\{27 \alpha^{3} /(1-\alpha)(1+2 \alpha+b / a)^{2}\right\}
$$

いをこれを上式のごとく $K_{P_{\mathrm{Cu}}}$ と扣き，(2) 式の対数をとれ ば, 前報の $\mathrm{Al}-\mathrm{Si}$ 合金および $\mathrm{Al}-\mathrm{Fe}$ 合金の場合と同様につ ぎの関係が得られる。

$$
\log a_{\mathrm{Al}}=\left(\log K_{P_{\mathrm{Cu}}}-\log K_{P}\right) / 2
$$

(5) 式に括ける平衡恒数の対数 $\log K_{P}$ の值はすでに前報 ${ }^{(3)}$ で求めたので, $\alpha$ 拈よび $b / a$ を測定して $\log K_{P_{\mathrm{Cu}}}$ の值を求

(5) O.Kubaschewski and E.LL.Evans : Metallurgical Thermochemistry, Pergamon Press, New York, (1958) . 
めるならば，(5) 式から溶融 $\mathrm{Al}-\mathrm{Cu}$ 合金中の $\mathrm{A} 1$ 活量を得 ることが可能となる，まず $\log K_{P_{\mathrm{Cu}}}$ の值を求めるために, $1200^{\circ}$ および $1100^{\circ} \mathrm{C}$ 飞执いて前記 6 種類の組成を有する 溶融 $\mathrm{Al}-\mathrm{Cu}$ 合金と $\mathrm{AlCl}_{3}$ とを反応せしめ, $\mathrm{AlCl}_{3}$ の反応率 $\alpha$ と混合ガス流速との関係を求めた. $1200^{\circ} \mathrm{C}$ に拈ける反応 率 $\alpha$ と混合ガス流速との関係を Fig. 1 に， $1100^{\circ} \mathrm{C}$ 飞拈け る同様の関係をFig.2 亿示す。両図上り明らかな上5に，

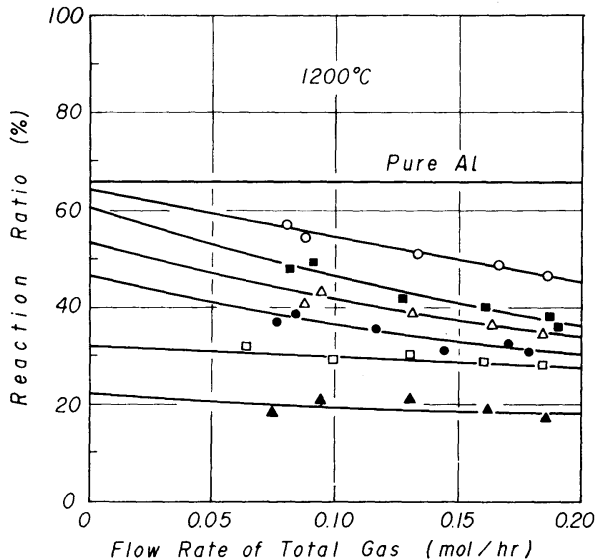

Fig. 1 Relation between reaction ratio of $\mathrm{AlCl}_{3}$ and flow rate of total gas for some liquid Al-Cu binary alloys at $1200^{\circ} \mathrm{C}$
O $N_{\mathrm{Cu}}=0.088$
$N_{\mathrm{Cu}}=0.396$
- $N_{\mathrm{Cu}}=0.169$
$\square N_{\mathrm{Cu}}=0.488$
$\triangle N_{\mathrm{Cu}}=0.292$
$\Delta N_{\mathrm{Cu}}=0.574$

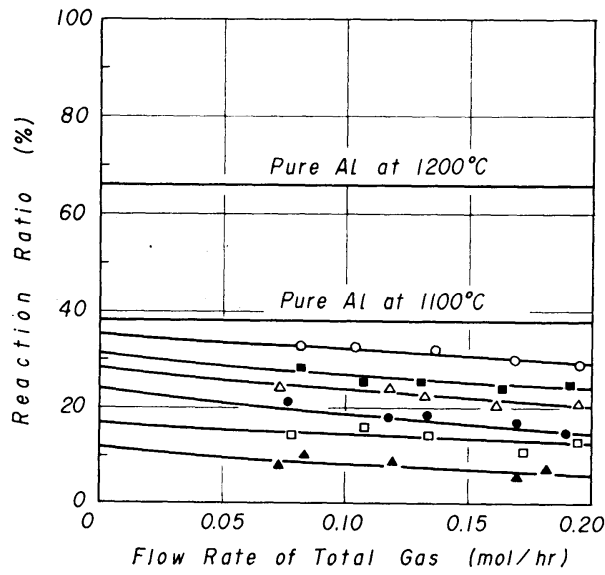

Fig.2 Relation between reaction ratio of $\mathrm{AlCl}_{3}$ and flow rate of total gas for some liquid Al-Cu binary alloys at $1100^{\circ} \mathrm{C}$
$N_{\mathrm{Cu}}=0.088$
- $N_{\mathrm{Cu}}=0.169$
- $N_{\mathrm{Cu}}=0.396$
$\Delta N_{\mathrm{Cu}}=0.292$
$N_{\mathrm{Cu}}=0.488$
- $N_{\mathrm{Cu}}=0.574$

$\mathrm{AlCl}_{3}$ の反応率は $\mathrm{Cu}$ 含有量の増大に伴なつて減少すると 同時に，各組成については混合ガス流速の增大に伴なつて 減少する傾向を示している，したがつて測定した各反応率 $\alpha$ は, 各温度各組成についての平衡反応率とは見なし得な い. そこで(4)式より求めた值を見かけの平衡值 $K_{P_{\mathrm{Cu}}}^{\prime}$ と し, $\log K_{P_{\mathrm{Cu}}}^{\prime}$ と混合ガス流速との関係を求めた. $1200^{\circ} \mathrm{C}$
に招いて求めた $\log K_{P_{\mathrm{C} 1}}^{\prime}$ と混合ガス流速との関係を Fig. 3 に, $1100^{\circ} \mathrm{C}$ に拉ける同様の関係を Fig.4 に示寸. Fig.4

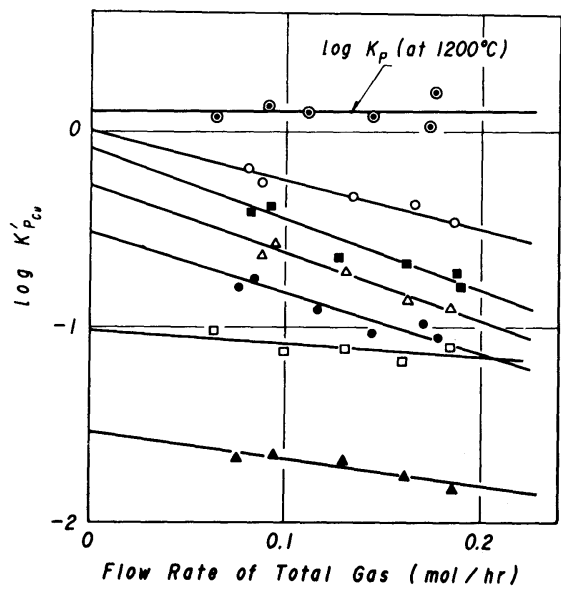

Fig.3 Relation between $\log K_{P_{\mathrm{Cu}}}^{\prime}$ and gas flow rate for some liquid Al-Cu binary alloys at $1200^{\circ} \mathrm{C}$
$\bigcirc N_{\mathrm{Cu}}=0.088$
- $N_{\mathrm{Cu}}=0.169$
- $N_{\mathrm{Cu}}=0.396$
$\triangle N_{\mathrm{Cu}}=0.292$
$\square N_{\mathrm{Cu}}=0.488$
$\triangle N_{\mathrm{Cu}}=0.574$

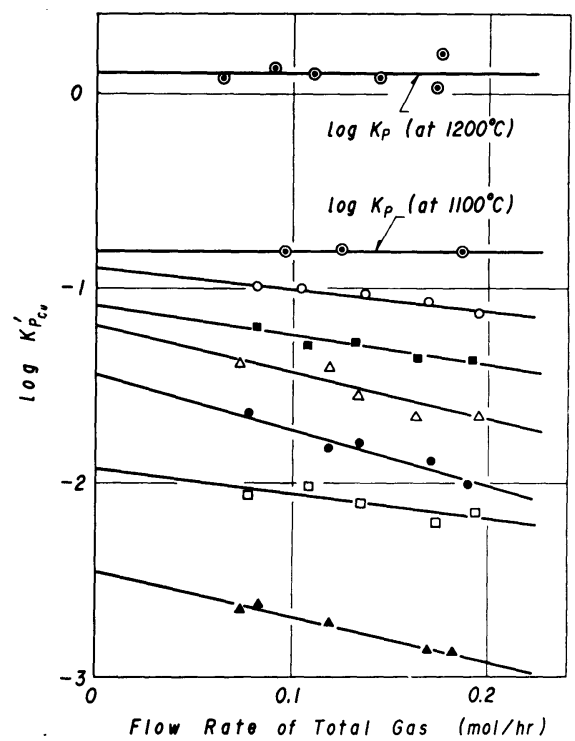

Fig. 4 Relation between $\log K_{P_{\mathrm{Cu}}}^{\prime}$ and gas flow rate for some liquid $\mathrm{Al}-\mathrm{Cu}$ binary alloys at $1100^{\circ} \mathrm{C}$
O $N_{\mathrm{Cu}}=0.088$
- $N_{\mathrm{Cu}}=0.169$
- $N_{\mathrm{Cu}}=0.396$
$\triangle N_{\mathrm{Cu}}=0.292$
$\square N_{\mathrm{Cu}}=0.488$
- $N_{\mathrm{Cu}}=0.574$

は $1100^{\circ} \mathrm{C}$ に扔ける結果であるが，比較のために $1200^{\circ} \mathrm{C}$ に 扬ける純 $\mathrm{Al}$ と $\mathrm{AlCl}_{3}$ との測定結果を同時に示した.

前報の $\mathrm{Al}-\mathrm{Si}$ 合金拉よび $\mathrm{Al}-\mathrm{Fe}$ 合金の場合と同様に，本 報の溶融 $\mathrm{Al}-\mathrm{Cu}$ 合金の場合にも直接に平衡偩 $\log K_{P_{\mathrm{Cu}}}$ を 得ることができなかつたので，各 $\mathrm{Cu}$ 濃度について測定値 $\log K_{P_{\mathrm{C} I}}^{\prime}$ を最小自乗法で処理し，混合ガス流速零に外挿し た值を平衡値 $\log K_{P_{\mathrm{Cu}}}$ として採用した。この值を(5)式に 
代入し， $1200^{\circ}$ 战よび $1100^{\circ} \mathrm{C}$ で求めた溶融 $\mathrm{Al}-\mathrm{Cu}$ 合金中 の $\mathrm{Al}$ 活量を Table 2 と示す.

Table 2 Activity values of $\mathrm{Al}$ in liquid $\mathrm{Al}-\mathrm{Cu}$ binary alloys at $1200^{\circ}, 1100^{\circ} \mathrm{C}$

\begin{tabular}{c|c|c|c}
\hline & $N_{\mathrm{Al}}$ & $a_{\mathrm{Al}}\left(1200^{\circ} \mathrm{C}\right)$ & $a_{\mathrm{Al}}\left(1100^{\circ} \mathrm{C}\right)$ \\
\hline 1 & 0.912 & 0.904 & 0.901 \\
2 & 0.831 & 0.806 & 0.754 \\
3 & 0.709 & 0.648 & 0.623 \\
4 & 0.604 & 0.490 & 0.483 \\
5 & 0.512 & 0.276 & 0.276 \\
6 & 0.426 & 0.150 & 0.150 \\
\hline
\end{tabular}

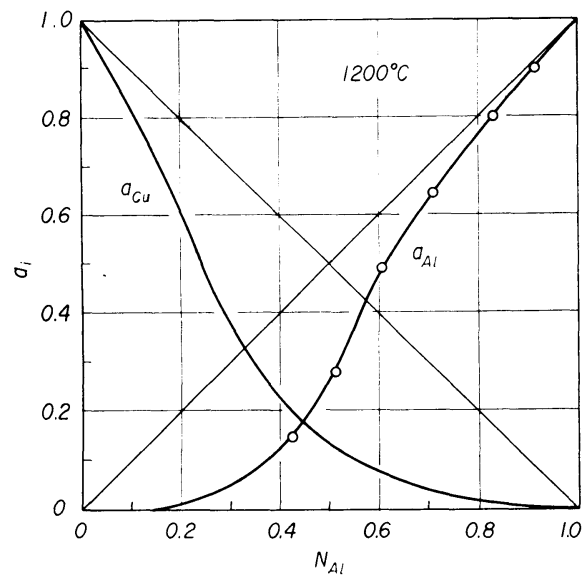

Fig.5 Activities of $\mathrm{Al}$ and $\mathrm{Cu}$ in their liquid binary system at $1200^{\circ} \mathrm{C}$

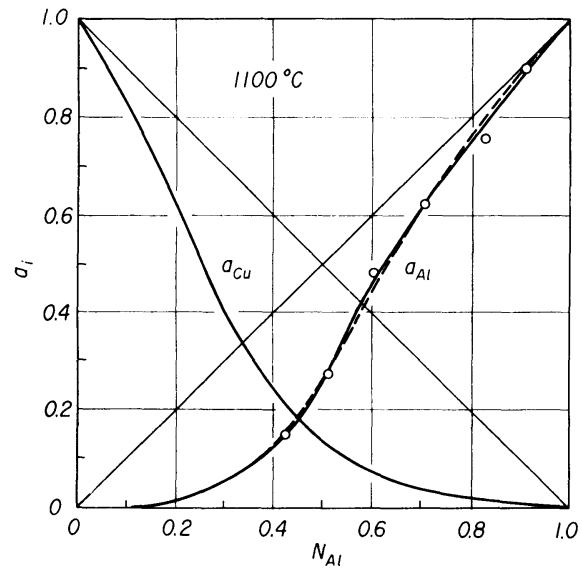

Fig.6 Activities of $\mathrm{Al}$ and $\mathrm{Cu}$ in their liquid binary system at $1100^{\circ} \mathrm{C}$ - - T.C. Wilder (at $\left.1100^{\circ} \mathrm{C}\right)$

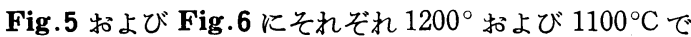
求めた $\mathrm{Al}$ の活量曲線扔よび $\mathrm{Al}$ 活量から Gibbs-Duhem の 改良式 ${ }^{(6)}$ で求めた $\mathrm{Cu}$ 活量を同時に図示した。 図より明ら かなように, $1200^{\circ}$ 扣よび $1100^{\circ} \mathrm{C}$ とを $\mathrm{Al}$ 活量は $N_{\mathrm{Al}}$ $<0.7, \mathrm{Cu}$ 活量は $N_{\mathrm{Cu}}<0.8$ の組成範囲で Raoult の法則か

(6) L.S.Darken and R.W.Gurry : Physical Chemistry of Metals, McGraw-Hill, (1953), New York.
らかなり大きく負に偏倚する傾向を示している．Fig.6の 破線は起電力測定法によるWilder ${ }^{(7)}$ の $1100^{\circ} \mathrm{C}$ に批ける測 定結果である. $N_{\mathrm{Al}}=0.85$ および 0.45 付近で本実験結果 よりわずかと大きく， $N_{\mathrm{Al}}=0.60$ 付近ではわずかに小さな 值となるが，本実験結果ときわめてよく一致した傾向を示 している.

\section{IV. 考察}

Fig.1 拉よび Fig. 2 亿見られるごとく, $\mathrm{AlCl}_{3}$ の反応率は 混合ガス流速の增大に伴なつて減少する傾向を示してい る.したがつて両図からは一見混合ガス流速の小さい場合 が気泡噴流法にとつて良好な条件であるかのごとく考兄ら れる、しかるにサブハライド製錬法では，アルゴンおよび $\mathrm{AlCl}_{3}$ ガス消費量を可能な限り少なくし，しかも単位時間 に多量の $\mathrm{Al}$ を $\mathrm{AlCl}$ として輸送することが得策であるか ら， $\mathrm{AlCl}_{3}$ の反応率のみからその条件の良否を結論するこ とは出来ない，すなわち単位時間に輸送される $\mathrm{Al}$ 量は， $\mathrm{AlCl}_{3}$ の反応率のみならず単位時間に輸送される $\mathrm{AlCl}_{3}$ 量 に依存し，(3)式より(6)式のごとく示される.

$$
\mathrm{Al}(\mathrm{g} / \mathrm{hr})=\mathrm{AlCl}_{3}(\mathrm{~g} / \mathrm{hr}) \times \alpha \times(53.96 / 133.35)
$$

したがつて(6)式に打ける $\mathrm{AlCl}_{3}$ の反応率 $\alpha$ と $\mathrm{AlCl}_{3}$ の輸 送速度との積を增すことによつて, $\mathrm{Al}$ の生成速度を增加さ せることが可能となる．しかるに混合ガス流速とは $\mathrm{AlCl}_{3}$ ガス流速と搬送ガス(アルゴソ)流速との和であるから，本 実験のごとくアルゴンガスと $\mathrm{AlCl}_{3}$ ガスとの混合モル比b/ $a$ を一定とした場合には，次式のごとく混合ガス流速が $\mathrm{AlCl}_{3}$ ガス流速の増大に比例して直線的に増加する。

混合ガス流速 $(\mathrm{mol} / \mathrm{hr})$

$$
=\mathrm{AlCl}_{3} \text { ガス流速 }(\mathrm{mol} / \mathrm{hr}) \times(1+b / a)
$$

すなわち(6)式に扔いて $\mathrm{A} 1$ の輸送速度を增加させるために $\mathrm{AlCl}_{3}$ ガス流速を増大させると，(7)式にしたがつて混合ガ ス流速が増大し，その結果 Fig.1 㧊よび Fig. 2 亿示したご とく $\mathrm{AlCl}_{3}$ の反応率 $\alpha$ が減少する結果となる．要するに $\mathrm{AlCl}_{3}$ の反応率と $\mathrm{AlCl}_{3}$ ガス流速とは互いに相殺する関係 にあり，両者の積によつて単位時間に得られる $\mathrm{Al}$ 量が決 定される。したがつていかなる条件のるとで単位時間に多 量の Al を得ることができるかを明らかにするために, Fig. 1 怙よび Fig.2 より $\mathrm{AlCl}_{3}$ の反応率执よび $\mathrm{AlCl}_{3}$ ガス流速 を読みとり，(6) 式から $\mathrm{A} 1$ の輸送速度と $\mathrm{AlCl}_{3}$ ガス流速 との関係を計算で求めた。 $1200^{\circ} \mathrm{C}$ での計算結果を Fig.7 に, $1100^{\circ} \mathrm{C}$ での結果を Fig. 8 亿示す． $1200^{\circ}$ 㧊よび 1100 ${ }^{\circ} \mathrm{C}$ ともに純 $\mathrm{Al}$ を原料とする場合には，前述のごとく混合 ガス流速の影響を受けず反応を平衡に到達させることがで きたので $\mathrm{AlCl}_{3}$ の反応率は一定值となり， $\mathrm{Al}$ の輸送速度 は $\mathrm{AlCl}_{3}$ ガス流速の增大に比例して直線的に増加するが, $\mathrm{Cu}$ 含有量が增加するにつれて $\mathrm{AlCl}_{3}$ ガス流速增大に伴な5 $\mathrm{A} 1$ の輸送速度の増加度は減少し, その減少程度は $\mathrm{Cu}$ 含有

(7) Thomas C.Wilder : Trans. AIME, 233 (1965), 1202. 
量の増加に伴なつて大きくなる傾向を示す.

要するに本実験条件の範囲内では, $\mathrm{AlCl}_{3}$ ガス流速を増

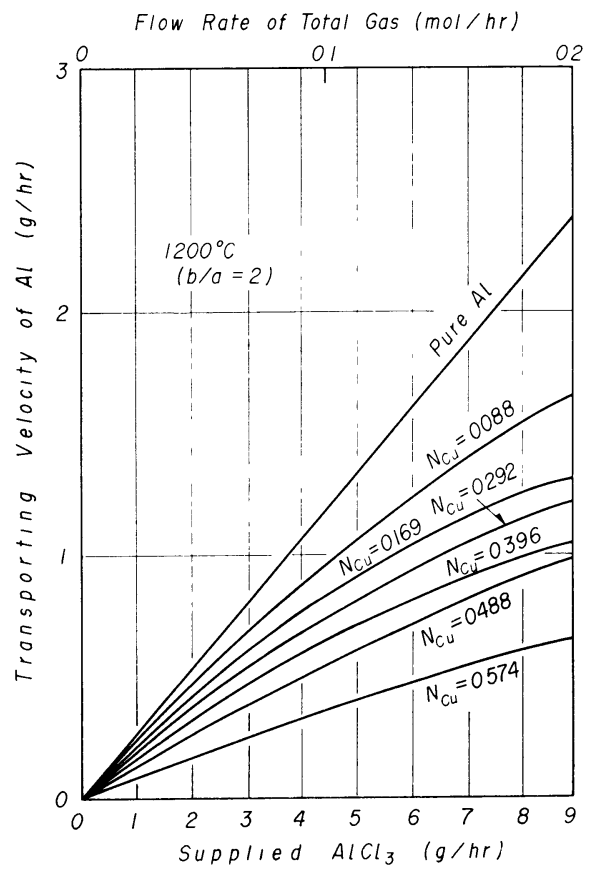

Fig.7 Relation between transporting velocity of $\mathrm{Al}$ and $\mathrm{AlCl}_{3}$ gas flow rate for some liquid $\mathrm{Al}-\mathrm{Cu}$ binary alloys at $1200^{\circ} \mathrm{C}$

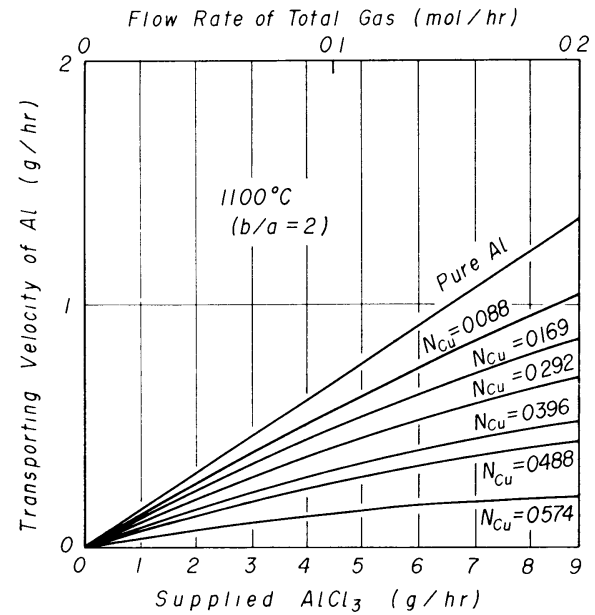

Fig. 8 Relation between transporting velocity of $\mathrm{Al}$ and $\mathrm{AlCl}_{3}$ gas flow rate for some liquid $\mathrm{Al}-\mathrm{Cu}$ binary alloys at $1100^{\circ} \mathrm{C}$

大させると, $\mathrm{AlCl}_{3}$ の反応率は減少するにもかかわらず， $\mathrm{Al}$ の輸送速度は增大するのであるから，混合ガス流速を 大きくして反応を行なわせれば単位時間に多量の $\mathrm{Al}$ を得 ることが可能となる。ただし $1100^{\circ} \mathrm{C}, N_{\mathrm{Cu}}=0.574$ の場合 のごとく $\mathrm{Cu}$ 含有量が多くしかも反応温度が低下すると， $\mathrm{Al}$ の輸送速度がほぼ飽和值に達し、アルゴンおよび $\mathrm{AlCl}_{3}$
の損失が大きくなる。

さらに $\mathrm{A} 1$ 輸送速度におよ.ぼす $\mathrm{Cu}$ 含有量の影響を明ら かにするために, $\mathrm{A} 1$ 輸送速度が最大の混合ガス流速 0.2

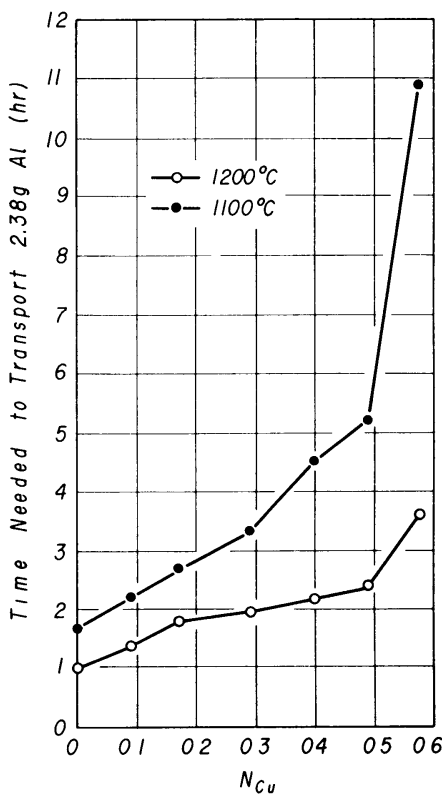

Fig.9 Time needed to transport $2.38 \mathrm{~g} \mathrm{Al}$ from some liquid Al-Cu binary alloys at total gas flow rate $0.2(\mathrm{~mol} / \mathrm{hr})$ $\mathrm{mol} / \mathrm{hr}$ に拈ける各 $\mathrm{Al}-\mathrm{Cu}$ 合金を原料と した場合の $\mathrm{Al}$ 輸送 速度を, 純 $\mathrm{A} 1$ の場 合を標準として比較 検討した。すなわち 原料に純 $\mathrm{Al}$ を使用 した場合に単位時間 内に輸送される $\mathrm{Al}$ 量と同量の $\mathrm{Al}$ を輸 送するに要する時間 を，各 $\mathrm{Cu}$ 濃度につ いて求め Fig. 9 に示 した。困から明らか なように, $\mathrm{Cu}$ 含有量 の増加によつて $\mathrm{Al}$ 輸送速度が著しく減 少し，かつ $1200^{\circ}$ と $1100^{\circ} \mathrm{C}$ とを比較す ると, $1100^{\circ} \mathrm{C}$ におい ては $100^{\circ} \mathrm{C}$ の温度低

下によつてその傾向がさらに強まり， $\mathrm{Al}$ 輸送速度におよぼ す反応温度の影響が顕著に現われている。

\section{V. 結}

（1）容融 $\mathrm{Al}-\mathrm{Cu}$ 合金中に $\mathrm{AlCl}_{3}$ ガスを微細な気泡として 気泡噴流せしめる方法により，原子分率 $N_{\mathrm{Cu}}=0 \sim 0.574$ の組成範囲に扣いて溶融 $\mathrm{Al}-\mathrm{Cu}$ 合金と $\mathrm{AlCl}_{3}$ との反応性を 追究し,さきに求めた平衡恒数を活用して溶融 $\mathrm{A} 1-\mathrm{Cu}$ 合金 中の $\mathrm{Al}$ 执よび $\mathrm{Cu}$ 活量を $1200^{\circ}$ および $1100^{\circ} \mathrm{C}$ で求めた. $\mathrm{Al}$ 活量は $N_{\mathrm{Al}}<0.7, \mathrm{Cu}$ 活量は $N_{\mathrm{Cu}}<0.8$ の組成範囲で Raoult の法則から大きく負に偏倚し，その形体は起電力測 定法によるWilder ${ }^{(7)}$ の $1100^{\circ} \mathrm{C} に$ にける測定結果ときわめ てよく一致した傾向を示す。

(2) $\mathrm{AlCl}_{3}$ の反応率と $\mathrm{AlCl}_{3}$ ガス流速とは互いに相殺す る関係にあり, $\mathrm{Al}$ の輸送速度は $\mathrm{AlCl}_{3}$ の反応率と $\mathrm{AlCl}_{3}$ ガ ス流速との積を増加させることによつて大さくすることが でさる. $\mathrm{AlCl}_{3}$ ガス流速を増大させると, $\mathrm{AlCl}_{3}$ の反応率が 減少するにもかかわらず $\mathrm{Al}$ の輸送速度は増大する.この 傾向は $\mathrm{Cu}$ 含有量の増加および反応温度の低下に伴なつて 著しく減少する。

終りに本研究に協力された, 当時の卒研生現在大阪大学 大学院在学中の 滝川 博工学士に深甚の謝意を表します。 